https://dx.doi.org/10.4314/ijs.v19i1.8

Ife Journal of Science vol. 19, no. 1 (2017)

\title{
EVIDENCE OF BASEMENT CONTROLLED FAULTING OF CRETACEOUS STRATA IN THE MIDDLE BENUE TROUGH, NIGERIA FROM LINEAMENT ANALYSIS OF GRAVITY DATA.
}

\author{
Awoyemi, M. O. ${ }^{1}$, Hammed, O. S. ${ }^{2}$, Falade, S. C. ${ }^{1}$ Arogundade, A. B. ${ }^{1}$, Olayode, F. A. ${ }^{1}$, \\ Olurin, O. T. ${ }^{3}$, Ajama, O. $\mathbf{D}^{1}$. and Onyedim, G. C. ${ }^{4}$ \\ ${ }^{1}$ Department of Physics and Engineering Physics, Obafemi Awolowo University, Ile-Ife, Nigeria. \\ ${ }^{2}$ Department of Physics, Federal University Oye-Ekiti, Ekiti, Nigeria. \\ ${ }^{3}$ Department of Physics, Federal University of Agriculture Abeokuta, Ogun State, Nigeria. \\ ${ }^{4}$ Department of Computer Science/Physics/Mathematics and Statistics, Federal University, Otuoke, Nigeria. \\ * Corresponding Author: Awoyemi, M. O. - ajobay@oauife.edu.ng
}

Hammed, O. S. - hammedolaide@yahoo.com, Falade, S. C. - faladesesan@gmail.com, Arogundade, A. B. arogundadeab@gmail.com, Olayode, F. A. - olayodef2002@yahoo.com, Olurin, O. T. - stolurin@yahoo.com,

Ajama, O. D. - ajamaojudoo@gmail.com, Onyedim, G. C.- onyedimgc@fuotuoke.edu.ng

(Received: 24th November, 2016; Accepted: 22nd March, 2017)

\section{ABSTRACT}

The Bouguer anomaly map of part of the Middle Benue Trough, Nigeria, was used to investigate the genetic relationship between the basement and intra-sedimentary structures in the study area. This was with a view to establishing the evidence of possible basement controlled faulting of the Cretaceous strata. Regional-residual separation of the anomalies was carried out to produce the gravity maps associated with crustal masses at deep and intermediate depth layers. The derived maps were further processed to produce Horizontal Gradient Magnitude (HGM) maps that were used to infer deep seated structures and structures existing at intermediate depth layer of the study area. HGM maxima of the anomaly at various altitudes of upward continuation were used to highlight the locations and dip directions of subsurface structures as controlled from deep to shallow zones. The results of this study showed that the structures at different depth layers dominantly trend in the same direction (N-S, NNE-SSW and NE-SW) and that the deep seated faults reflect structurally in the overlying sedimentary column. It was therefore concluded that basement faulting might have influenced the structures in the overlying sedimentary rocks.

Keywords: Cretaceous Sediments, Lineaments, Azimuth-frequency, Fault Propagation.

\section{INTRODUCTION}

The interpretation of gravity data over sedimentary basins provides insights into basement and intra-sedimentary structures and composition at local, intermediate and regional scales. Such studies are particularly useful in defining the location, depth and extent of buried structures and compositional boundaries. They also reveal the relationships between fault/fracture systems in the sedimentary strata and the underlying basement. It has been recognized that basement fault reactivation has significant control on sedimentation and fault propagation in intra-cratonic basins (Sanford et al., 1985; Benkhelil, 1988; Kalota and Nelson, 1991; McBride and Nelson, 1999). Benkhelil (1989) invoked the reactivation of strike-slip movement on old deep-seated faults to explain the formation of major structural features such as the en echelon folds and pull-apart basins which abound within the Benue Trough. Therefore, the establishment of a genetic relationship between basement and intra-sedimentary faults can establish the fact that basement fault reactivation has structural and geological implications on sedimentation and subbasins formation. This study has applications in tectonic studies and exploration programmes as they reflect unmapped deep-seated faults and their expressions in the overlying sediments. In many places, such features act as guides or barriers to fluid or magma flow or form favourable structural environments for mineralization and are therefore important in oil and gas, mineral, groundwater and geothermal studies.

The present study involved qualitative and quantitative interpretation of gravity data to delineate both deep basement structural features and their shallow intra-sedimentary expressions in parts of the Middle Benue Trough, Nigeria. 


\section{DESCRIPTION OF THE STUDY AREA}

The study area, bounded by latitudes $7^{\circ} 00 \mathrm{~N}$ and $9^{\circ} 30 \mathrm{~N}$, and longitudes $8^{\circ} 30 \mathrm{E}$ and $11^{\circ} 00 \mathrm{E}$, is located within the Middle Benue Trough (MBT), as shown in Figure 1. The Benue Trough is a NESW trending sedimentary basin with an approximate length of about $800 \mathrm{~km}$ and $150 \mathrm{~km}$ wide. The southwestern and northeastern ends of the Benue Trough are bounded by the Niger Delta and the Chad Basin respectively. Regionally, the trough is part of an early Cretaceous rift complex known as the West and Central African Rift System. Geological report by Burke et al. (1972) showed that sedimentation began in the Benue Trough during the Albian (c. $110 \mathrm{Ma}$ ) and it was of marine type being terminated by a period of deformation in the Santonian (c. 80 Ma.). The deformation resulted in faulting and folding of the Cretaceous sediments. Benkhelil (1982) also explained that the movements controlled both extensional and compressional phase of deformation observed within the Benue Trough. These movements might also be responsible for the normal and thrust faults mapped in the MBT by Ajayi and Ajakaiye (1981) and the thrust might have been responsible for folding of the sediments parallel to the axis of the trough. The Benue Trough is known for the occurrence of extensive igneous activities which took place in the lower Cretaceous. The activity phase is most intense during the late Albian (Ofoegbu, 1984); intrusive and extrusive rocks occur in the Middle Benue and appeared to terminate within the Lafia Formation.

Stratigraphically, the Cretaceous sedimentary succession (beginning from the oldest to the youngest) consists of the Asu River Group, the Awe, Keana, Eze-Aku, Awgu and Lafia Formations. Nwachukwu (1985) suggested that exploration targets in the basin include both the Sub-Santonian and Super-Santonian sediments, with the Eze-Aku Group, Awgu Shale, and Nkporo Shale being more prospective than the stratigraphically lower Asu River Group. No postCretaceous sediments occur in the middle Benue Trough. Volcanic activity was also relatively minor in scale and was concentrated in its southern part. A notable occurrence is the phonolithic trachyte of Wase Rock described by Wright (1989). Basalt flows occur around Awe and dolerite sills of Cenozoic age have been encountered within the Lafia Formation (Obaje et al., 1994). The preMesozoic rocks, which form the basement, consist mainly of granulitic gneisses, migmatites, older granites, younger granites, porphyries and rhyolites, migmatites and gneisses.

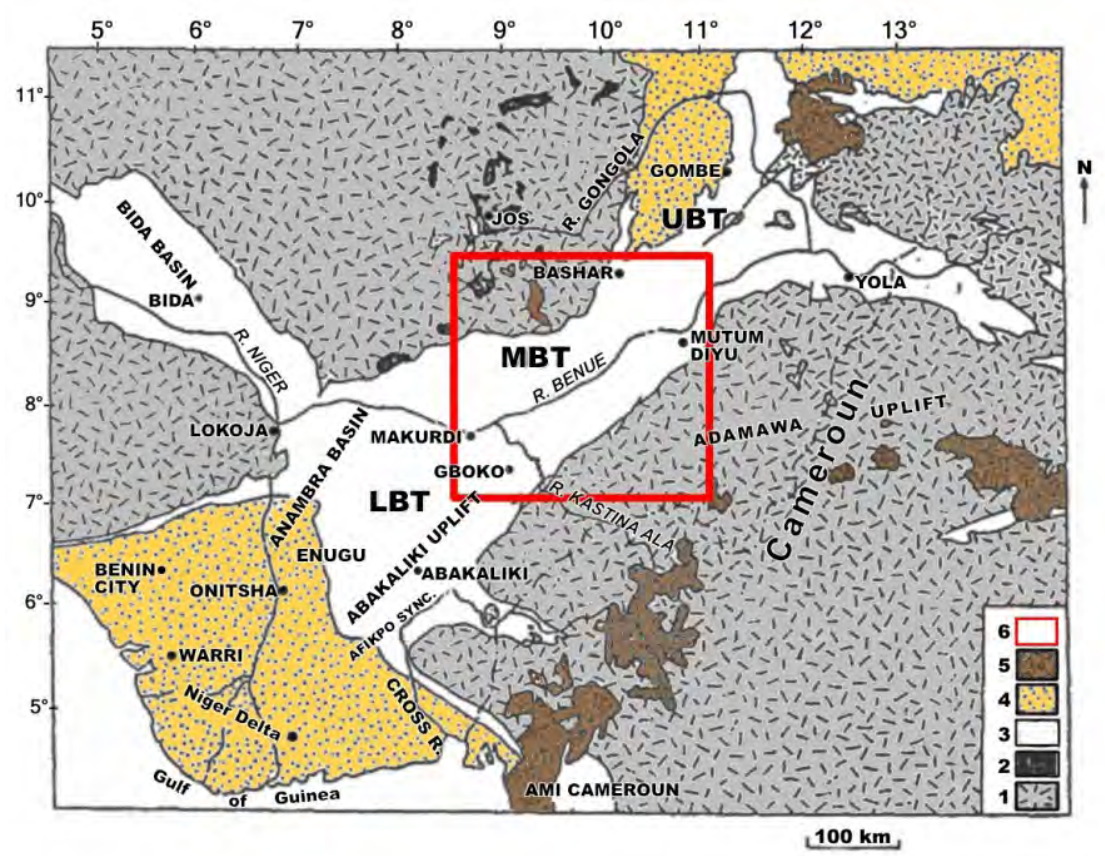

Figure 1: Geological Map of the Benue Trough and its Environs (after Zaborski, 1998). LBT - Lower Benue Trough; MBTMiddle Benue Trough; UBT- Upper Benue Trough. 1. Precambrian. 2. Jurassic "Younger Granites". 3. Cretaceous. 4. PostCretaceous sediments. 5. Cenozoic Recent basalts including those of Cameroon Volcanic Line. 6. Study Area. 


\section{MATERIALS AND METHODS}

The digital gravity data used in this study were extracted from Getech's processed gravity data. The obtained data was resampled and gridded at $1.0 \mathrm{~km}$ spacing using the minimum curvature procedure (Webring, 1981) to produce the Bouguer anomaly map for the area (Figure 2).

In sedimentary basins, it is generally assumed that gravity responses are caused mainly by features of the bedrock geology because density contrasts within the sedimentary section are comparatively small. Densities in the basement probably range from $2.6 \times 10^{3}$ to $3.2 \times 10^{3} \mathrm{~kg} / \mathrm{m}^{3}$ (metasediments to mafic units). Changes in the gravity field may be caused by different rock types of varying densities separated by contacts typified by faults or fractures in the basement and the sedimentary sequence, or by relative changes in depth to the basement. However, the sedimentary strata can display significantly large anomalies if intruded by basic intrusive or due to the presence of faults which have propagated from the basement. To investigate if this is the case in the study area, the Bouguer anomaly data was first subjected to regional trend removal. The first, second and third order 2D polynomial surface fittings were tried on the data (see Figure 3), but the second order gave the best expression for the regional trend, and was thus chosen. The residual Bouguer anomaly map obtained after the removal of the regional trend is presented in Figure 4. Spectral analysis of the residual Bouguer anomaly data was then carried out to separate the gravity effects of the basement sources from the effects of the intra-sedimentary sources and the resulting data were processed to produce horizontal gradient magnitude maps. Furthermore, total horizontal derivative of the Bouguer anomaly map coupled with upward continuation at differential depths were analyzed to map the dip direction of the fracture patterns in the study area.



Figure 2: Bouguer Anomaly Map of the Study Area. Dashed line represents the demarcation of the Basement-sedimentary contact. 

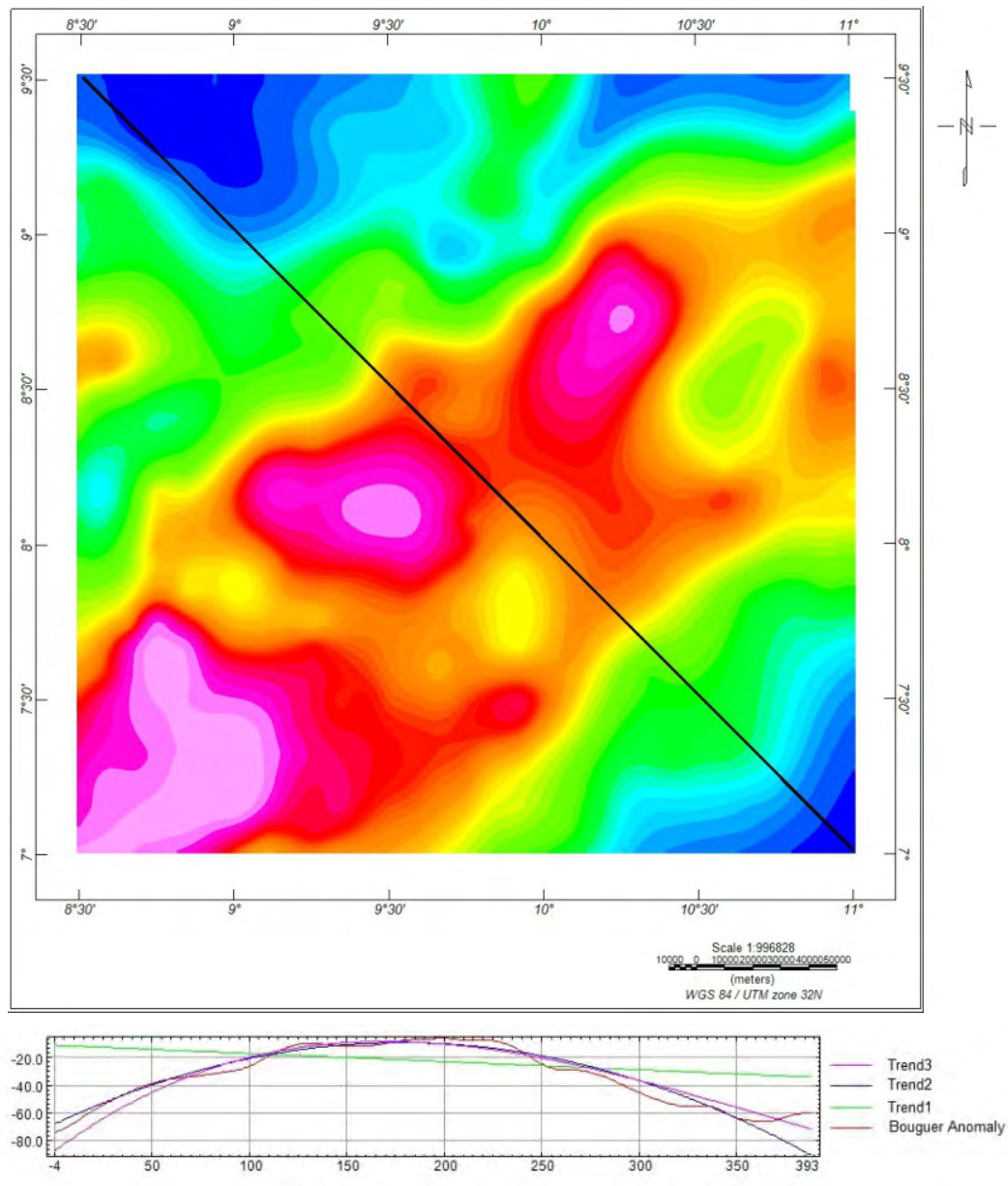

Figure 3: Profile Showing the Fits of Regional Trends to Data. The second order trend (trend2) was chosen.



Figure 4: Residual Bouguer Anomaly Map of the Study Area. 
Spectral Analysis and Filtering of Gravity Data

A gravity anomaly map can be considered to represent the sum effect of the density variations at various depths and of different magnitudes. In order to produce the anomaly maps associated with the basement and intra-sedimentary sources, spectral analysis and band pass filtering of the gravity anomaly map were carried out. The power spectrum can often be broken up into series of straight lines segments as shown in Figure 5. Each segment represents the cumulative response of an ensemble of sources at a given depth. The depth is directly proportional to the slope of the line segment (Naidu, 1968; Spector and Grant, 1970).

The methodology adopted in this study required the separation of anomalies due to deep sources (basement unit) from those associated with the shallower sources. Filtering is a way of separating signals of different wavelengths in order to isolate, and hence enhance anomalous features of certain wavelengths. The technique is sometimes referred to as regional-residual separation. The spectral analysis of the Bouguer anomaly data yielded depths for different density layers. The cut off wavenumbers obtained for the shallow layer (area marked layer 1 in Figure 5) ranged between 0.2283 and 0.0753 cycles $/ \mathrm{km}$. The intermediate depth layer (layer 2) has a cut off range of 0.0753 0.0389 cycles $/ \mathrm{km}$, while deep depth layer (layer 3 ) has a cut off range of $0.03881-0.0023$ cycles $/ \mathrm{km}$. Layer 2 and layer 3 were respectively used to obtain the gravity fields due to the intermediate sources (Figure 6a) and deep sources (Figure 6b) respectively.

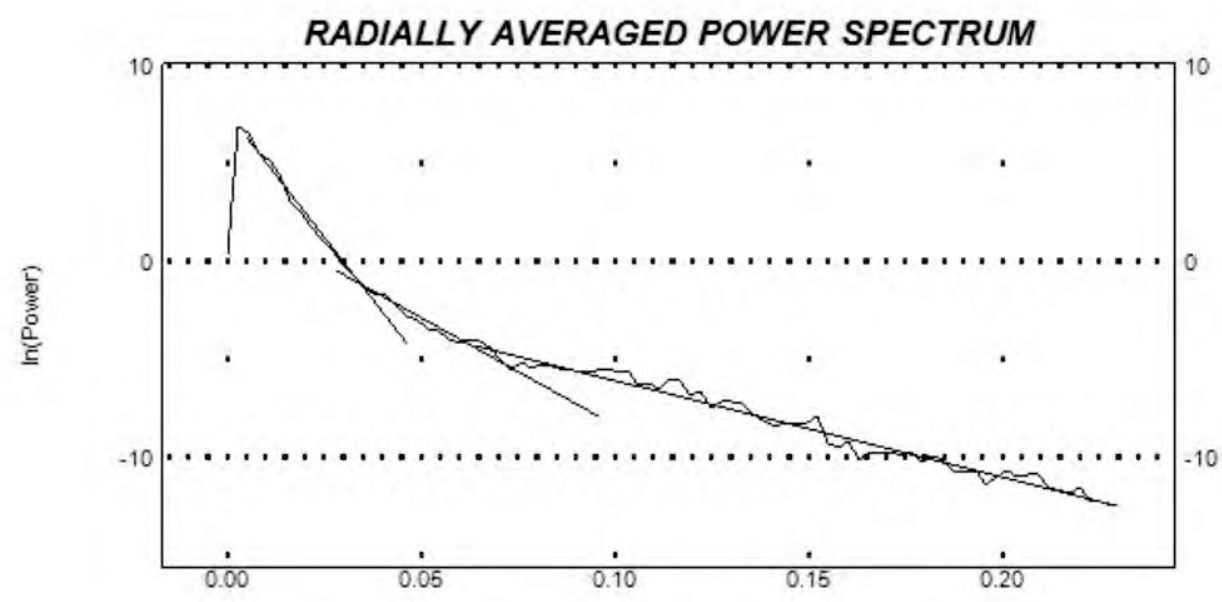

DEPTH ESTIMATE



Figure 5: The Power Spectrum of the Bouguer Gravity Anomaly Field of the Study Area. The linear segments correspond to the density layers used to compute the cut-off wavenumbers. 


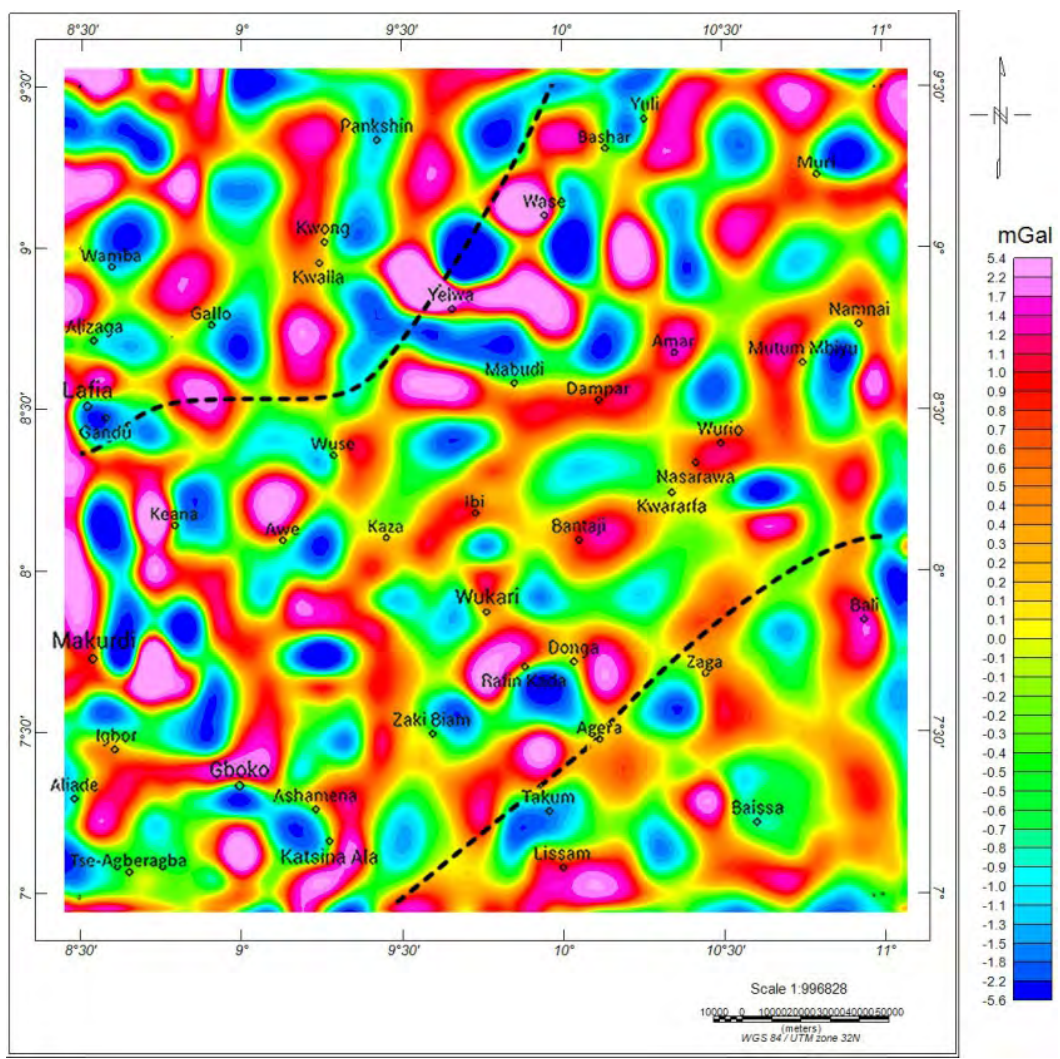

Figure 6a: Residual Gravity Field Showing Anomalies due to Sources at Intermediate Depths (Layer 2).

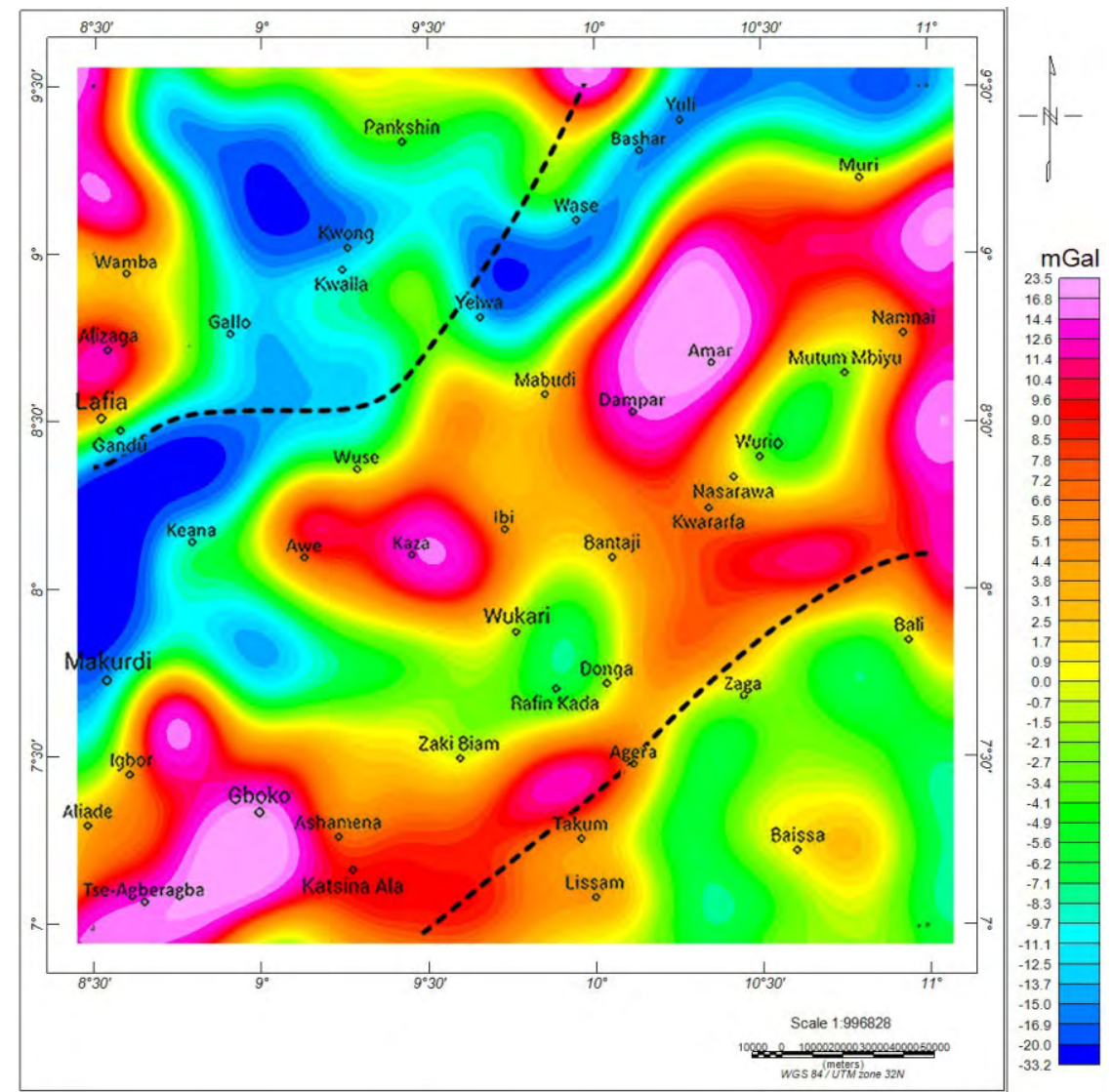

Figure 6b: Residual Gravity Field Showing Anomalies due to Sources at Deep Depths (Layer 3). 
Horizontal Gradient Magnitude and Upward Continuation of Gravity Data

The Horizontal Gradient Magnitude (HGM) technique is used to locate the boundaries of density contrast from gravity data (Cordell, 1979). Horizontal derivative maps highlight anomaly pattern discontinuities (which might occur at faulted boundaries) and can provide higher resolution and greater accuracy at wider line spacing (Hogg, 2004). The amplitude of the horizontal gradient magnitude as given by Grauch and Cordell (1987) is expressed as equation (1).

$\operatorname{HGM}(\mathrm{x}, \mathrm{y})=\left\{(\partial G / \partial x)^{2}+(\partial G / \partial y)^{2}\right\}^{\frac{1}{2}}$

where $\partial \mathrm{G} / \partial \mathrm{x})$ and $\partial \mathrm{G} / \partial \mathrm{y})$ are the horizontal derivatives of the gravity field in the $\mathrm{x}$ and $\mathrm{y}$ directions respectively. The horizontal gradient method is relatively insensitive to noise because it only requires calculations of the two first-order horizontal derivatives of the field (Phillips, 2000).

The gravity fields due to the sources at intermediate and deep depths (Figures 6a and 6b) were processed to obtain the HGM maps in Figures $7 \mathrm{a}$ and $7 \mathrm{~b}$ respectively. The maxima extracted from these HGM maps were used to derive the lineaments (presumed to be fractures and faults) at the intermediate and deep depths.

The application of horizontal gradient magnitude technique and upward continuation allows the mapping of discontinuities and their dip directions (Archibald et al., 1999). This technique has been applied to upward-continued data at various altitudes $(1,4,8,13,16$, and $20 \mathrm{~km})$ above the measurement surface. The upward continuation processing of the Bouguer gravity map at various altitudes, followed by determining the horizontal gradient maxima at each level yielded the progressive migration of the maxima which indicate the approximate dip direction of the faults. If structures are vertical, all the maxima from the different levels overlap. This method has been used to characterize some faults related to major tectonics in the study area. 


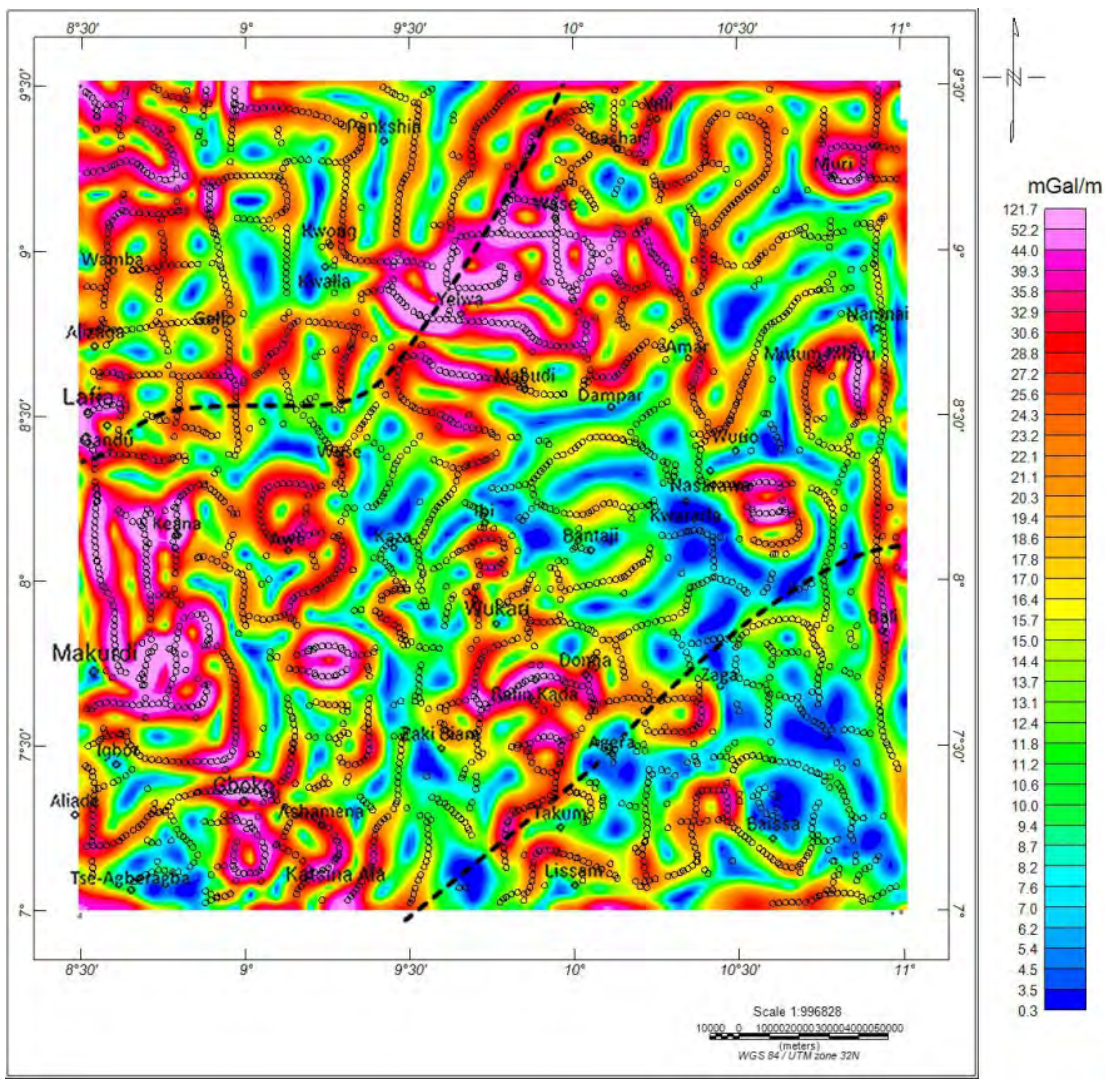

Figure 7a: Horizontal Gradient Magnitude Map of anomalies from Intermediate Depths. The black circles superimposed are the Maxima.

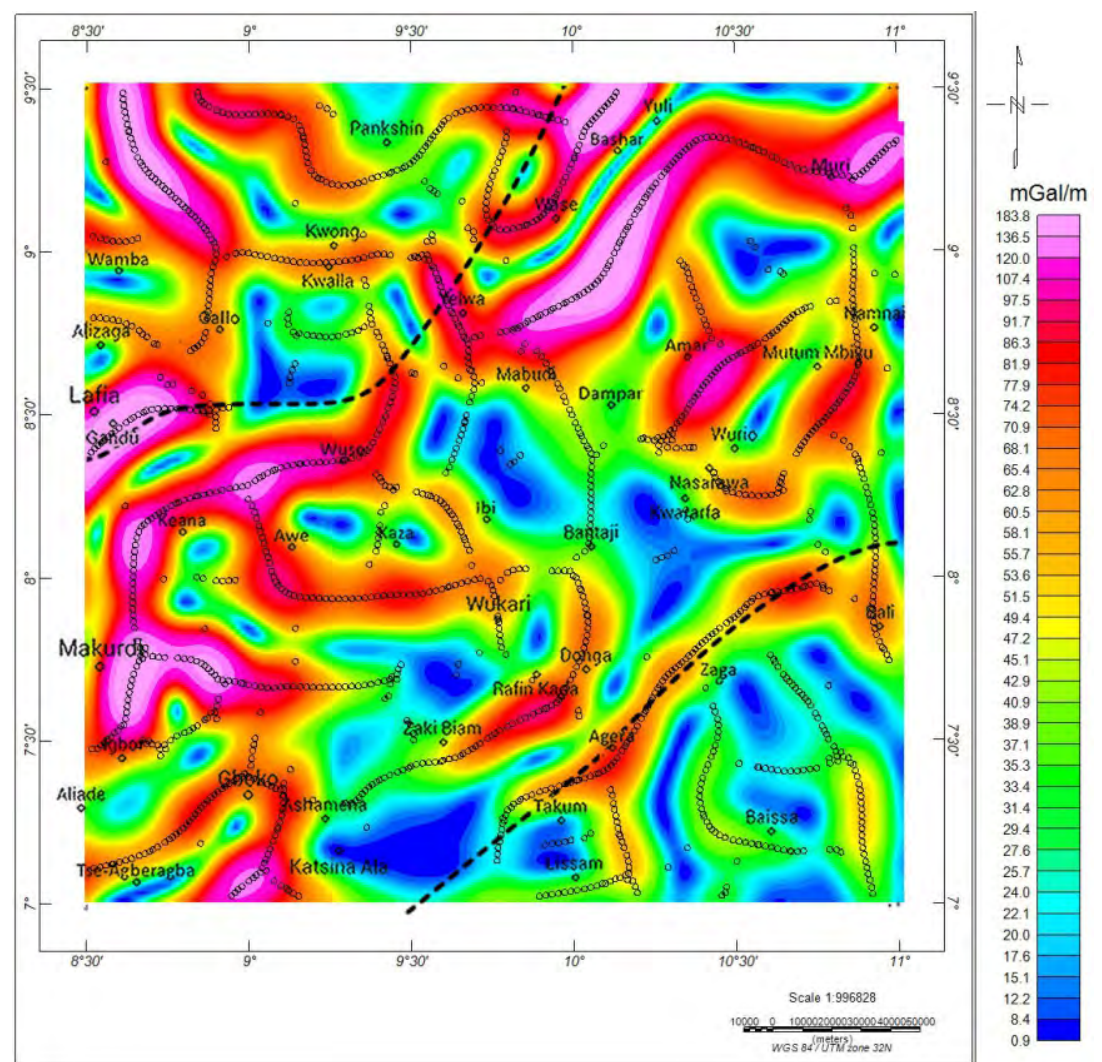

Figure 7b: Horizontal Gradient Magnitude Map of anomalies from Deep Depths. The black circle superimposed are the Maxima. 


\section{RESULTS AND DISCUSSION}

The gravity anomalies in the study area, as shown in Figure 2, dominantly trend in the NE-SW direction. The magnitude of the anomalies ranges between -77.1 and $17.4 \mathrm{mGal}$. The Bouguer anomaly map shows the combined signatures of various crustal masses in the study area. The anomaly maps associated with the sources at the intermediate and deep depths (Figures $6 \mathrm{a}$ and $6 \mathrm{~b}$ respectively) were processed to obtain the HGM maps in Figures $7 \mathrm{a}$ and $7 \mathrm{~b}$. The black dots on the HGM maps indicate the peaks of the HGM, which are interpreted as the locations of the geological lineaments (such as faults, fractures or lithological contacts) in the study area. A linear feature can be considered structurally significant if it extends over a distance of about $4 \mathrm{~km}$ or more (Onyedim and Ocan, 2001); In some cases, however, short but aligned segments may also satisfy this criterion (Onyedim et al., 2009). The structural maps (Figures $8 \mathrm{a}$ and $8 \mathrm{~b}$ ) inferred from the HGM maps of the intermediate and deep crustal masses show that the study area is dissected by many structures that trend in various directions; indicating a complex tectonic history of the study area.

Based on the tectonic forces affecting the study area, the trends of the inferred structural lineaments were grouped into sixteen cardinal points and presented on a frequency-rose diagram. The orientations of the inferred structures within the intermediate depth layer (Figure 9a) show that the lineaments in this layer trend predominantly in the N-S, followed by NNE-SSW and NE-SW directions. Other minor trends in the layer include NNW-SSE, E-W, ENEWSW, NW-SE and WNW-ESE. Beneath the intermediate depth layer, the orientations of the inferred geological structures as shown in Figure $9 \mathrm{~b}$ is predominantly N-S, followed by NNE-SSW and NE-SW. The minor trends include the ENEWSW, WNW-ESE, NNW-SSE, E-W and NW-SE.
According to Omosanya et al. (2012), structures that trend in the same direction were produced by the same tectonic process or processes. The predominant N-S trend observed at both intermediate and deep depths is known as the meridian trend (Benkhelil and Robineau, 1983). The N-S and E-W trends were linked, by Genik (1992), to the structural grain that results from the reactivation of the pre-trough weak zones, which were created during the crustal consolidation stage in late Precambrian to Cambrian (750 - 550 $\mathrm{Ma}$ ) by the Pan-African orogeny in the western African mobile belt. The meridian trend (N-S) is more frequent in the basin than on the exposed basement, and most of the mineralizations $(\mathrm{Pb} / \mathrm{Zn}, \mathrm{Ba}, \mathrm{Qz})$ in the Benue Trough occur in association with the meridian trends (Nwajide, 2013). Nwajide (2013) believed that the role of the meridian trend in the evolution of the trough is limited to secondary components of the late Cretaceous conjugate shear system and to the Tertiary extensional regime which accompanied the initiation of the Cameroon volcanic line. The NE-SW and NW-SE trends in the study area are indicative of Pan-African orogeny fracture systems that predate the rifting of the Benue and Niger Troughs and can be interpreted as significant features of the tectonic framework of the Nigerian Basement Complex (Kogbe, 1983; Ananaba, 1983; Oluyide, 1988). According to Onyedim et al. (2004), the NW-SE trending faults form a conjugate pair with the NE-SW faults within the fracture system of the Nigerian Basement Complex. The Benue trend of lineaments, according to Nwajide (2013), is between $40^{\circ}$ and $73^{\circ}$ (NE-SW and ENE-WSW) and is almost always dominant in the whole Benue Trough. The pre-existing NE-SW and ENEWSW trending ductile/brittle shear zones are periodically reactivated in response to regional tectonism and they control the evolution of the trough (Nwajide, 2013). 
Awoyemi et al.: Evidence of Basement Controlled Faulting of Cretaceous Strata

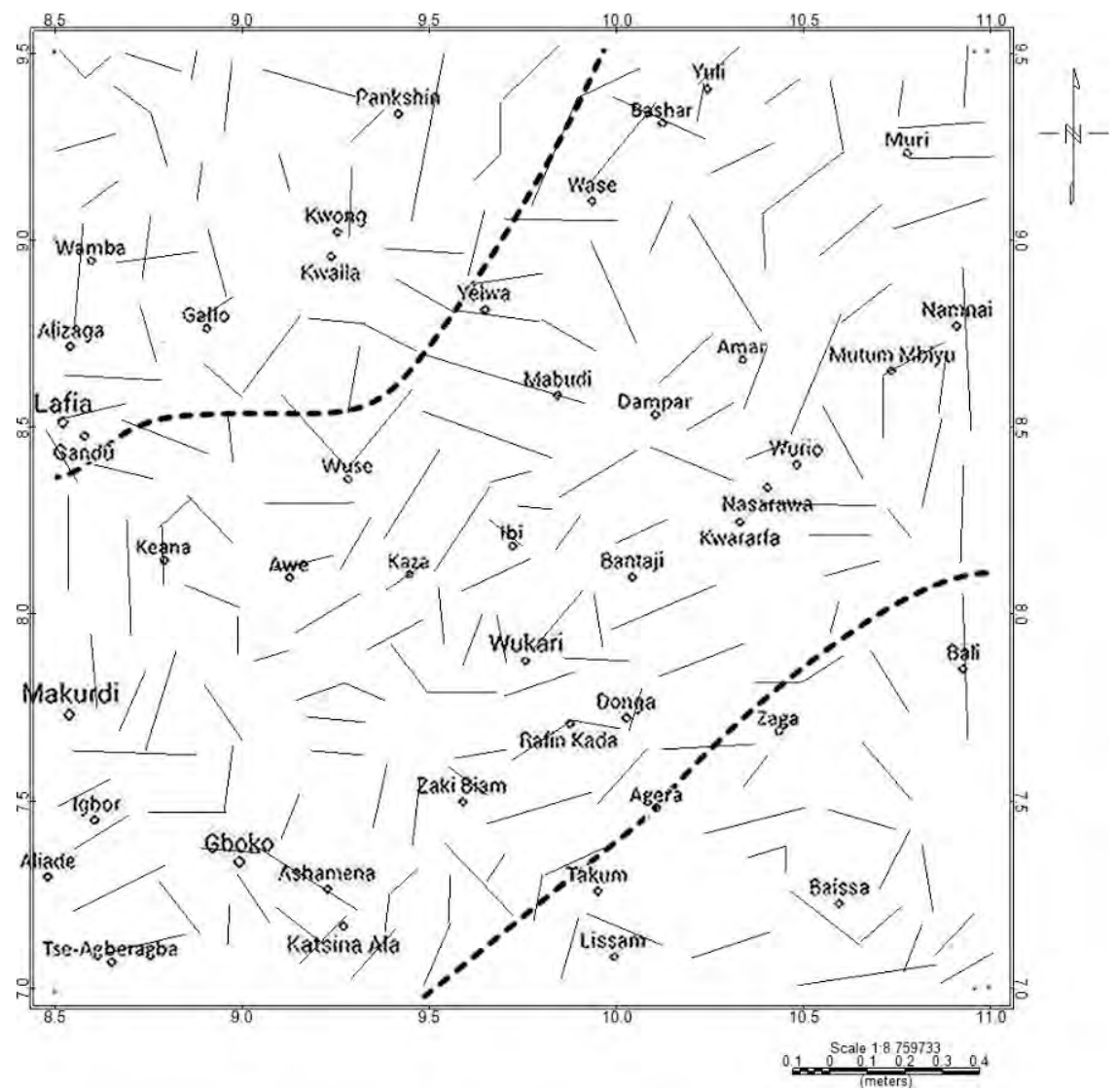

Figure 8a: Inferred Structural Map of lineaments at the Intermediate Depths.



Figure 8b: Inferred Structural Map of lineaments at Deep Depths. 


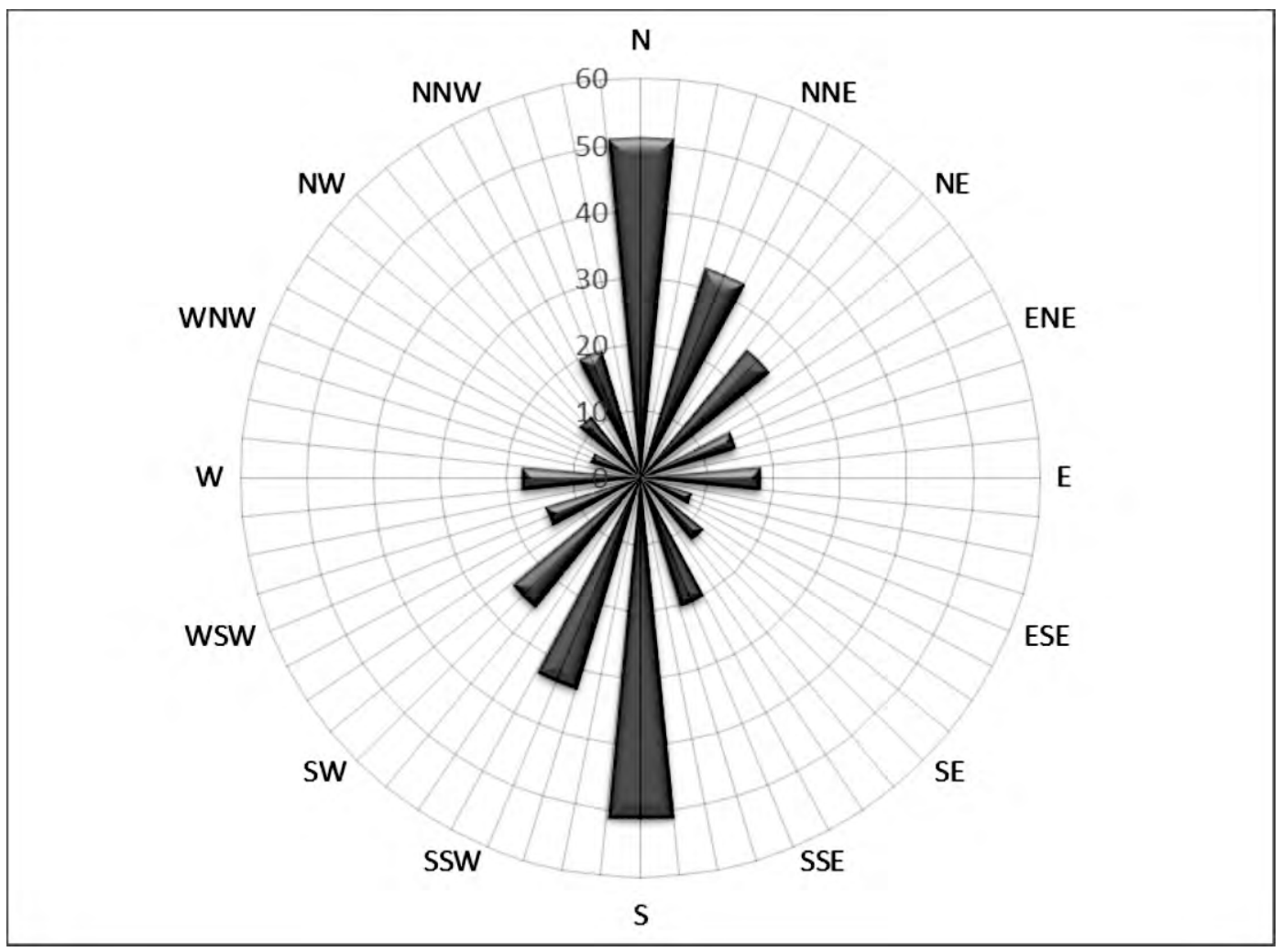

Figure 9a: Rose Diagram Showing the Orientation of the Inferred Structures at the Intermediate Depths.



Figure 9b: Rose Diagram Showing the Orientation of the Inferred Structures at Deep Depths. 
The dominant structural trends (N-S, NNE-SSW and NE-SW) observed at both intermediate and deep depths within the study area suggest that the structures within the sediments were mostly initiated by the underlying basement faulting. Majority of the faults within the basin are most likely basement-evolved faults; movements along the basement faults would have led to some high angled faults in the overlying strata. In order to illustrate the possible extension of the basement faults into the overlying sedimentary column, the Bouguer anomaly map was upward continued to $1,4,8,13,16$ and $20 \mathrm{~km}$ altitudes, and horizontal gradient maxima were calculated for each level and plotted. The resulting composite map of the HGM maxima (Figure 10) shows the major boundaries between areas of high density contrast with several lineaments corresponding to the major structural features affecting the study area. The degree of importance (in depth) of these lineaments was determined by the continued presence of the local maxima for increasingly high altitudes of upward continuation. Structures that were created by the movement of basement fault blocks are directly coincident with the underlying faults (Gay, 2012). The propagation of each fault as controlled from deep within the basement to shallow depths are indicated by the existence of linear features from deep (black) to shallow (green) zones. The direction in which the linear features are progressively shifted from the shallow to deep zones indicates the down dip direction. The study area spans both sedimentary and basement complex terrains. The lineaments mapped (Figure 10) are representatives of faults, fractures, folds, or lithological contacts from near top (green) to deep (black) within the basement in the basement complex terrain, and from the intrasedimentary layer (green) to basement layer (black) in the sedimentary terrain. Most of the structures in the study area show vertical/subvertical dips in the sedimentary terrain than in the Basement Complex region. The deep seated structures in the sedimentary terrain were presumed to be controlled by the continental extension of the transform faults associated with Proto-Atlantic equatorial shear zone (Fairhead and Okereke, 1987). The continued movement of some basement blocks along the weak zones would have resulted in fracturing and the formation of faults, fold and stratigraphic features in the overlying sediments.

In the sedimentary section, the composite map (Figure 10) shows that almost all the elongated deep seated structures reflect structurally in the overlying sediments. However, structures in zones Z1-Z6 were mapped at shallow layers and show no continuity downwards; this implies that structures in these zones are only intrasedimentary and might not have been directly influenced by the basement tectonics. The structures could have resulted from secondary tectonic activities of the basement since most of the structures strike in the direction of some nearby deep seated structures. 




Figure 10: Composite Map of Bouguer Anomaly HGM Maxima at Different Upward Continuation Heights.

\section{CONCLUSIONS}

The influence of the basement structures on the overlying sedimentary rocks of the Middle Benue Trough, Nigeria, has been investigated using the gravity method. The results showed that the structures within and beneath the basin dominantly trend in the N-S, NNE-SSW and NESW directions. This high degree of directional correlation among the trends of the structures at different depth layers and the evidence of basement fault propagation revealed by the horizontal gradient maxima of the Bouguer anomaly at several upward continuation heights strongly suggest that structures within the basin were initiated by the movement of the underlying basement fault blocks. It is therefore concluded in this study that the faulting of Cretaceous strata in the Middle Benue Trough is controlled by the tectonic activities of the basement.

\section{ACKNOWLEDGEMENTS}

The authors extend their sincere appreciation to the office of the Shell Professor of Geophysics through Prof. S.B. Ojo of the Department of Geology, Obafemi Awolowo University, Ile-Ife for releasing the Bouguer Gravity data used in this research work. We also appreciate Prof. M.O. Olorunfemi and the reviewers for their laudable contributions.

\section{REFERENCES}

Ajayi, C.O. and Ajakaiye, D.E. 1981. The origin and peculiarities of the Nigerian Benue Trough: Another look from recent gravity data obtained from the middle Benue. Tectonophysics 80: 285-303.

Ananaba, S.E. 1983. Evaluation of remote sensing application to geophysical studies in Nigeria. Unpublished Ph. D. Thesis, Ahmadu Bello University, Zaria, Nigeria.

Archibald, N. J., Gow, P., and Boschetti, F. 1999. Multiscale Edge Analysis of Potential Field Data Exploration, Geophysics 30: 3844. 
Benkhelil, J. 1982. The Benue Trough and Benue Chain. GeologicalMagazine 119:155-168.

Benkhelil, J. 1988. Structure et evolution geodynamique du basin intracontinantal de la Benue (Nigeria). Bulletin Centres Researchers Exploration-Production ElfAquitaine 12: 29-128.

Benkhelil, J. 1989. The origin and evolution of the Cretaceous Benue Trough (Nigeria). Journ. African Earth Sci. 8: 251-282.

Benkhelil, J., and Robineau, B. 1983. Le fosse de la Benoue est il um rift? Centre Rech Eplor Prod Elf Aquitaine Bull7:315-321.

Burke, K.C., Dessauvagie, T.F.J. and Whiteman, A.J. 1972. Geological history of the Benue valley and adjacent areas. African Geology. University of Ibadan Press, Ibadan.

Cordell, L. 1979. Gravimetric expression of graben faulting in Santa Fe country and the Espafiola Basin, New Mexico, in Guidebook to Santa Fe Country, 30th Field Conference, R. V. Ingersoll (ed.), New Mexico Geological Society 59-64.

Fairhead, J.D. and Okereke, C.S. 1987. A regional gravity study of the West African rift system in Nigeria and Cameroon and its tectonic interpretation. Tectonophysics 143: 141-159.

Gay, S.P. Jr. 2012. Joints, Linears, and Lineaments - The Basement Connection. Adapted from oral presentation given at AAPG Rocky Mountain Section Meeting, Grand Junction, Colorado, 9-12 September. Applied Geophysics, Inc., Salt Lake City, UT. Search and discovery article \#41083.

Genik, G.J. 1992. Regional framework, structural and petroleum aspects of rift Basins in Niger, Chad and Central African Republics (C.A.R), Tectonophysics 213: 169185.

Grauch, V.S J. and Cordell, L. 1987. Limitations of determining density or magnetic boundaries from the horizontal gradient of gravity or pseudogravity data. Short note, Geophysics 52(1): 118-121.

Hogg, S. (2004): GT-Gradient tensor gridding, geologic structure example, http://www.shageophysics.com/

Kalota, D.R. and Nelson, J.W. 1991. Tectonic history of the Illinois Basin. In: Leighton,
M.W., Kalota, D.R., Oltz, D.F., Eidel, J.J. (Eds.), Interior Cratonic Basins. Am. Assoc. Pet. Geol., Tulsa, Oklahoma, Mem. 51:263-285.

Kogbe, C.A. 1983. Geological interpretation of Landsat imageries across central Nigeria. Journ. Afri. Earth Sci. 1:313-320.

McBride, J.H. and Nelson, W.J. 1999. Style and origin of Mid-Carboniferous deformation in the Illonois Basin, USA; ancestral Rockies deformation? Tectonophysics 305: 249-273.

Naidu, P.S. 1968. Spectrum of potential field due to randomly distributed sources. Geophysics 33: 337-345.

Nwachukwu, J.I. 1985. Petroleum Prospects of Benue Trough, Nigeria. Am. Assoc. Pet. Geol., Bull. 69 (4): 601-609.

Nwajide, C.S. 2013. Geology of Nigeria's Sedimentary Basins. CSS Bookshops Limited, Lagos, Nigeria. pp. 27-130.

Obaje, N.G., Ligous, B. and Abaa, S.I. 1994. Petrographic composition and depositional environments of Cretaceous coals and coal measures in the middle Benue Trough of Nigeria. International Journal Coal Geology 26, 233-260.

Ofoegbu, C.O. 1984. Interpretation of Aeromagnetic anomalies over the Lower and Middle Benue Trough of Nigeria. Geophys. J. R. Astron. Soc. 79: 813-823.

Oluyide, P.O. (1988). Structural trends in the Nigerian Basement Complex. Precambrian Geology of Nigeria. Geol. Surv. Nigeria. 93-98.

Omosanya, K. O., Akinbodewa A. E., Mosuro, G. O. 2012. Integrated Mapping of lineaments in Ago-Iwoye SE, SW NigeriaIntl.J. Sci. Technol. 1(2):68-79.

Onyedim, G.C. and Ocan, O.O. 2001. Correlation of SPOT imagery lineaments with geological fractures in part of Ilesha area, Southwestern Nigeria. Journ. Min. \& Geol. 37:15-22.

Onyedim, G.C., Arubayi, J.B., Ariyibi, E.A., Awoyemi, M.O. and Afolayan, J.F. 2004. Elements of wrench fault tectonics deduced from SLAR imagery and aeromagnetic data in part of the middle Benue Trough, Nigeria. Journ. Min. Geol. 41 (1): 51-56. 
Onyedim G.C., Alagoa K.D., Adedokun I.O., Aderogba A.A. and Ovuru C. 2009. Mapping High-Angle Basement Faults in the Middle Benue Trough, Nigeria from Gravity Inversion Surface. Earth Sciences Research Journal13(2): 140-147.

Phillips, J. 2000. Locating magnetic contacts: A comparison of the horizontal gradient, analytic signal, and local wavenumber methods: $70^{\text {th }}$ Annual International Meeting, SEG, Expanded Abstracts, 402-405.

Sanford, B.V., Thompson, F.J. and McFall, G.H. 1985. Plate tectonics - A possible controlling mechanism in the development of hydrocarbon traps in Southwestern Ontario. Bull Can Pet. Geol. 33: 52-71.

Spector, A., and Grant, F.E. 1970. Statistical models for interpreting aeromagnetic data, Geophysics 35: 293-302.

Webring, M. 1981. MINC: A gridding program based on minimum curvature. USGS Open File Report 81-1230

Wright, J.B. 1989. Volcanic Rocks in Nigeria. Geology of Nigeria, Rock View (Nigeria) Ltd, Jos, Nigeria. 125-173.

Zaborski, P.M. 1998. A review of the Cretaceous System in Nigeria. Africa Geoscience Review 5 (4):385-483. 